\title{
Phytoplankton biodiversity trends in nanobubble aerated shrimp farming at Probolinggo coast, East Java, Indonesia
}

\author{
NOVERITA DIAN TAKARINA ${ }^{1, \vartheta}$, SUYUD WARNO UTOMO ${ }^{2,3}$, LILY SUSANTI ${ }^{2, v,}$, \\ NURUL TAUFIQU ROCHMAN ${ }^{4}$, DEDI CAHYADI ${ }^{5,6}$, HARDI JUNAEDI ${ }^{5,7}$, HENRY KASMAN HADI SAPUTRA $^{5,8}$, \\ RIZKI NUGRAHA SAPUTRA ${ }^{5,6}$ \\ ${ }^{1}$ Department of Biology, Faculty of Mathematics and Natural Sciences, Universitas Indonesia. J1. Lingkar UI, Depok 16424, West Java, Indonesia. \\ Tel.: +62-21-7270163,78849009, Fax.: +61-21-78849010, `email: noverita.dian@ @ci.ui.ac.id \\ ${ }^{2}$ School of Environmental Science, Universitas Indonesia. J1. Salemba Raya No. 4, Jakarta Pusat 10430, Jakarta, Indonesia. Tel.: +62-21-31930251, \\ vemail: lily.susanti@ui.ac.id \\ ${ }^{3}$ Department of Environmental Health, Faculty of Public Health, Universitas Indonesia. Jl. Lingkar UI, Depok 16424, West Java, Indonesia \\ ${ }^{4}$ Research Center for Metallurgy and Materials, Indonesian Institute of Sciences, PUSPITEK. South Tangerang 15314, Banten, Indonesia. \\ ${ }^{5}$ Nanobubble Karya Indonesia, Ltd. Jl. Raya Serpong, South Tangerang 15314, Banten, Indonesia \\ ${ }^{6}$ Nano Center Indonesia. Jl. Raya Serpong, South Tangerang 15314, Banten, Indonesia \\ ${ }^{7}$ Department of Agricultural Industry, Faculty of of Agricultural Technology, Institut Pertanian Bogor. Jl. Lingkar Akademik, Kampus Dramaga, Bogor \\ 16680, West Java, Indonesia \\ ${ }^{8}$ Department of Aquaculture Technology and Management, Vocational School, Institut Pertanian Bogor. Jl. Kumbang 14, Kampus Cilibende, Bogor \\ 16151, West Java, Indonesia
}

Manuscript received: 29 October 2020. Revision accepted: 29 November 2020.

\begin{abstract}
Takarina ND, Utomo SW, Susanti L, Rochman NT, Cahyadi D, Junaedi H, Saputra HKH, Saputra RN. 2020. Phytoplankton biodiversity trends in nanobubble aerated shrimp farming at Probolinggo coast, East Java, Indonesia. Biodiversitas 21: $5906-5914$. Phytoplankton is known as an important factor in shrimp farming and its abundance and biodiversity are varied. Nanobubble aeration is one of current aquaculture treatments used in brackish water shrimp ponds. This study aimed to investigate phytoplankton biodiversity trends in nanobubble and control ponds within 21-day observation period. The measured water quality parameters were dissolved oxygen (DO), $\mathrm{NH}_{4}{ }^{+}, \mathrm{NO}_{2}{ }^{-}, \mathrm{pH}$, salinity, temperature, and water clarity. Data analysis includes calculation of abundance and biodiversity using ShannonWiener (H') index and correlation using Principal Component Analysis (PCA). A total of 11 phytoplankton species from 5 divisions was recorded. The results show increasing trends in phytoplankton abundance, species, and H'. In pond with nanobubble, $\mathrm{H}^{\prime}$ increased from 0.322 (95\%CI: 0.074-0.718) to 0.561 (95\%CI: 0.208-0.916) after 21 days, while in control pond, H' increased from 0.199 (95\%CI: 0.000 0.520 ) to 0.326 (95\%CI: $0.000-0.683$ ). In the nanobubble pond, species showing increasing trend in abundance were Pleurosigma sp., Nitzchia sp., Anabaena sp., Oscillatoria sp., and Microcystis sp. Whereas, species showing a declining abundance trend were Chlorella sp. and Amphora sp. According to PCA, phytoplankton abundance was positively correlated with $\mathrm{pH}$, water clarity, $\mathrm{DO}^{-} \mathrm{NO}_{2}^{-}$, and negative correlation with salinity, temperature, and $\mathrm{NH}_{4}^{+}$.
\end{abstract}

Keywords: Biodiversity, brackish water, nanobubble, phytoplankton

\section{INTRODUCTION}

In brackish water shrimp ponds, phytoplankton was known to grow naturally (Araújo and Garcia 2005). Alonso-Rodriguez and Páez-Osuna (2003) found that phytoplankton abundance and diversity often vary, influenced by several water quality parameters including water clarity, temperature, $\mathrm{pH}$, and salinity. Water quality plays a significant role in influencing phytoplankton productivity as well as the growth rate of shrimps. Phytoplankton is a bioindicator of environmental conditions and water quality within ponds because phytoplankton is sensitive to sudden water quality changes and phytoplankton provides immediate responses to low dissolved oxygen levels, toxic contaminants, poor food quality or abundance and predation (Case et al. 2008).

Since water quality is an important factor for the phytoplankton presence in brackish water shrimp ponds, a solution to improve the water quality has been considered extensively. One of the solutions is by applying nanobubble treatment in the ponds. The principle of nanobubble is the changes and modifications of aeration systems to increase the concentration of dissolved oxygen (DO) in cultivation water. This can be achieved by supplying DO to water. Nanobubble is an ultra-small gas bubble in liquid with diameters of micron and submicronorder, and characterized by its slow buoyancy, negative surface charges, free radical formation, and increased water molecule mobility. Nanobubbles in water were generated using decompression, gas-water circulation, ultrasonic waves, and small-porous-glass membrane (Ohmori et al. 2015; Temesgen et al. 2017). Mahasri et al. (2018) observed the increase of DO from 6.5 to $25.0 \mathrm{ppm}$ in cultivation water using nanobubble. Wang et al. (2018) reported that nanobubble can effectively improve the DO in water and maintain DO for a longer period. Using nanobubble treatment, the average DO levels were recorded at $7.76 \%$ higher than control. 
The increased DO in brackish water shrimp ponds resulted from nanobubble treatment can benefit the phytoplankton. This considers that besides having capabilities to produce oxygen, phytoplankton also depends on the DO for respirations. Takarina et al. (2017) showed that the DO level has positive correlation with the phytoplankton biodiversity. Using nanobubble can increase DO, provide DO for phytoplankton respiration, and increase biodiversity as well. Furthermore, several studies have reported the biodiversity of phytoplankton. In brackish ponds in Sumbawa, there were 34 species under 4 divisions (Cyanophyta, Chlorophyta, Diatom, and Dinoflagellate) (Mansyah et al. 2020). Java coasts were also known to have high phytoplankton diversity. In ponds located in Rembang, Central Java, there were 14 species of Cyanophyta, Chlorophyta, and Dinoflagellate (Umami et al. 2018), while in ponds located in Subang, West Java, Sudinno et al. (2015) found 10 phytoplankton species.

The current phytoplankton biodiversity in Probolinggo has been studied by Utojo (2015), however, this study only covered phytoplankton biodiversity in brackish ponds managed under conventional aeration. Meanwhile, the study about the impact of modified aeration to improve the phytoplankton biodiversity in brackish water shrimp ponds is still limited. The objective of this study is to analyze how the modified aeration in the form of nanobubble aeration treatment can influence the phytoplankton biodiversity and water quality parameters in brackish water shrimp pond in Probolinggo coast, East Java, Indonesia.

\section{MATERIALS AND METHODS}

\section{Study area}

The study was conducted in July 2020 in a brackish water shrimp pond treated with nanobubble in Probolinggo coast, East Java, Indonesia (Figure 1). The pond was used as commercial farm for shrimp cultivation (Penaeus vannamei) Post Larvae 8 . The sampling period was 21 days and the sampling activities were conducted three times on July 7 ( $7^{\text {th }}$ day), 14 ( $14^{\text {th }}$ day), and 21 (21st day), 2020. The experiment was conducted in two shrimp ponds, this includes a pond treated with nanobubble and a pond without treatment (control).

\section{Nanobubble aeration treatment}

The nanobubble machine unit sizing $500 \times 600 \times 700$ $\mathrm{mm}(\mathrm{LxWxH})$ used in this study was NB S-2, which was developed by Nanobubble Karya Indonesia Ltd., South Tangerang, Indonesia, and patented by Pusat Penelitian Fisika LIPI No. P00201903600.

In this study, the nanobubble was used to generate oxygen bubbles with DO levels ranging from $10 \mathrm{mg} . \mathrm{L}^{-1}$ to $20 \mathrm{mg} . \mathrm{L}^{-1}$ with a bubble size of $<200 \mathrm{~nm}$. The flow rate was 120 liter per minute with coverage of 200-500 $\mathrm{m}^{2} /$ nanobubble unit. Four nanobubble machines were set up in the brackish water shrimp pond (Figure 1).

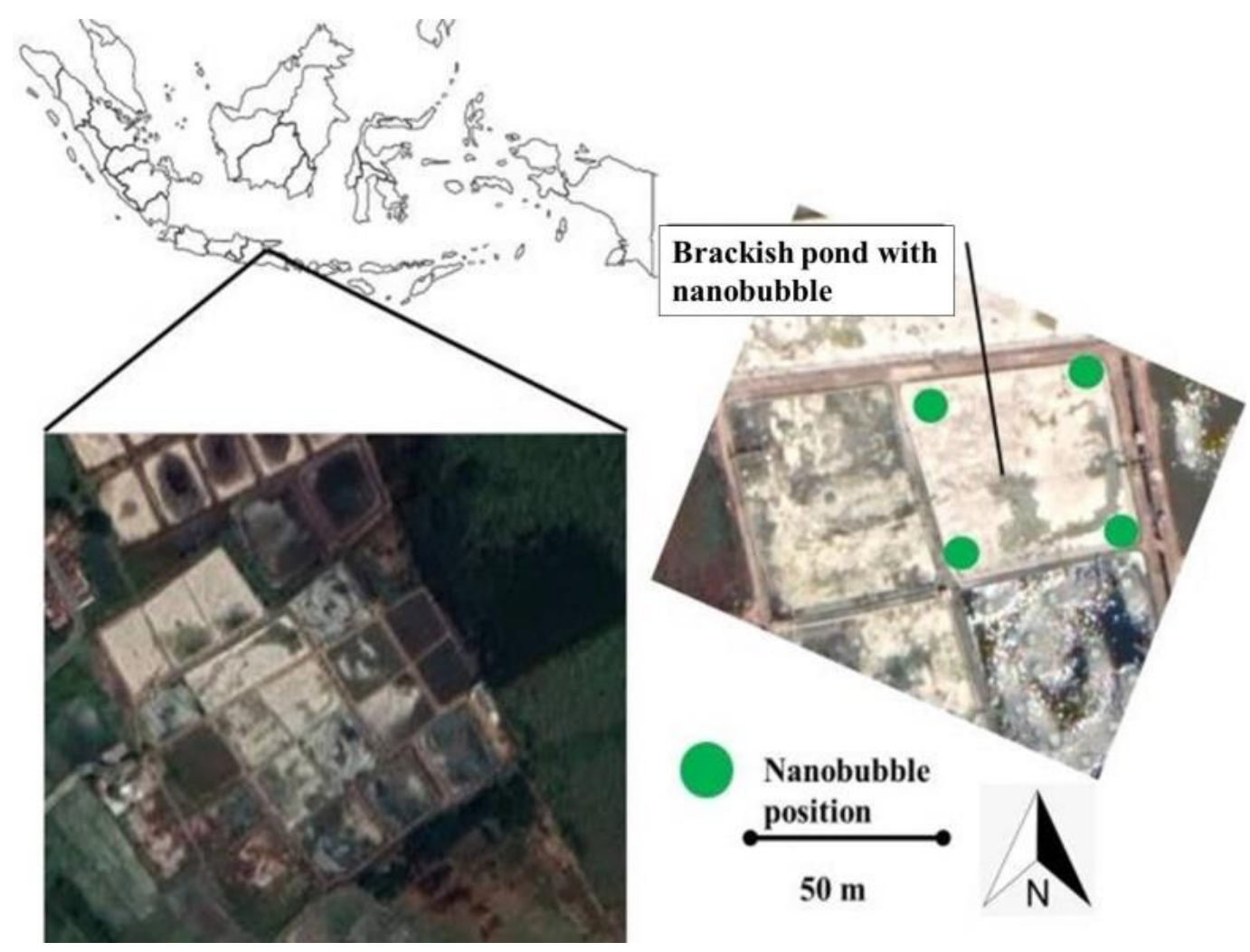

Figure 1. The location of a brackish pond with nanobubble aeration treatment in shrimp farm in Probolinggo coast, East Java, Indonesia 
Table 1. Water quality parameter methods

\begin{tabular}{|c|c|c|}
\hline Parameter & Unit & Sampling methods \\
\hline \multicolumn{3}{|l|}{ Biological } \\
\hline Phytoplankton & cells $/ \mathrm{mL}$ & Kemmerer plankton method \\
\hline \multicolumn{3}{|l|}{ Chemical } \\
\hline Dissolved oxygen (DO) & $\mathrm{mgL}^{-1}$ & YSI Pro 20 \\
\hline $\mathrm{NH}_{4}^{+}$ & ppm & $\begin{array}{l}\text { Genesys }{ }^{\mathrm{TM}} 30 \text { Thermofisher } \\
\text { spectrophotometer }(\lambda=640 \mathrm{~nm})\end{array}$ \\
\hline $\mathrm{NO}_{2}^{-}$ & ppm & $\begin{array}{l}\text { Genesys }{ }^{\mathrm{TM}} 30 \text { Thermofisher } \\
\text { spectrophotometer }(\lambda=543 \mathrm{~nm})\end{array}$ \\
\hline $\mathrm{pH}$ & & YSI pH100 \\
\hline Salinity & ppt & Atago refractometer \\
\hline Temperature & ${ }^{\circ} \mathrm{C}$ & YSI pH100 \\
\hline Clarity & $\mathrm{cm}$ & Secchi disk \\
\hline
\end{tabular}

\section{Procedures}

The measured water quality parameters included dissolved oxygen (DO), $\mathrm{NH}_{4}^{+}, \mathrm{NO}_{2}^{-}, \mathrm{pH}$, salinity, temperature, and water clarity (Table 1). The DO was measured with YSI Pro 20, pH and temperature with YSI pH100, and water clarity using Secchi disk depth. Three replications of water quality measurements were conducted in treatment and control brackish water shrimp ponds on July 7, 14, and 21, 2020. In total there were nine subsamples for each pond.

\section{Phytoplankton analysis}

Plankton samples were collected three times in brackish water shrimp ponds, on July 7, 14, and 21, 2020 using Kemmerer plankton method (Morsy 2011). The plankton samples were collected in a $250 \mathrm{~mL}$ bottle and preserved with $4 \%$ formaldehyde. Samples were then stored in a cool place in the laboratory and kept in the dark, to prevent color from changing to the solution, until further analysis. In the laboratory, samples were identified using Olympus CX 21 binocular microscope. Then, phytoplankton samples were identified to genus and species levels using several identification guides (Newell and Newell 1977; Yamaji 1984; Tomas 1997).

Phytoplankton enumeration was conducted using the Sedgwick-Rafter counting chamber on sample fraction method and the results are denoted in cells $/ \mathrm{mL}$. The Sedgwick-Rafter counting cell equation is:

Phytoplankton cells $=\frac{\text { cell counted }}{\text { counting chamber volume }} \times \frac{1}{\text { concentration factor }} \times \frac{1000}{\text { liter }}$

Where counting chamber volume equals to 1 and concentration factor is 100 .

\section{$\mathrm{NH}_{4}^{+}$and $\mathrm{NO}_{2}^{-}$analysis}

$\mathrm{NH}_{4}{ }^{+}$and $\mathrm{NO}_{2}^{-}$contents were analyzed using spectrophotometry method. Prior to the analysis, water samples were filtered, and $10 \mathrm{~mL}$ were then subtracted and placed in a test tube. For $\mathrm{NH}_{4}{ }^{+}$analysis, $0.5 \mathrm{~mL}$ phenol $10 \%, 0.5 \mathrm{~mL}$ sodium nitroprusside $0.5 \%$, and $1 \mathrm{~mL}$ oxidizing reagent were added to the $\mathrm{NH}_{4}{ }^{+}$test tube and stirred. Then, the $\mathrm{NH}_{4}{ }^{+}$solution was stored for 60 minutes at room temperature. While for $\mathrm{NO}_{2}^{-}$analysis, $0.2 \mathrm{~mL}$ sulfanilamide $1 \%$ and $0.2 \mathrm{~mL} \quad \mathrm{~N}$-(1-naphthyl) ethylenediamine $1 \%$ was added to the $\mathrm{NO}_{2}{ }^{-}$test tube and stirred. Then, the $\mathrm{NO}_{2}^{-}$solution was stored for 120 minutes at room temperature. After that, $\mathrm{NH}_{4}{ }^{+}$and $\mathrm{NO}_{2}{ }^{-}$solutions were analyzed using Genesys ${ }^{\mathrm{TM}} 30$ Thermofisher spectrophotometer. The spectrophotometer wavelength for $\mathrm{NH}_{4}{ }^{+}$and $\mathrm{NO}_{2}{ }^{-}$analyses were $640 \mathrm{~nm}$ and $543 \mathrm{~nm}$, respectively.

\section{Biodiversity data analysis}

The mean \pm standard error and confidence interval $(\mathrm{CI})$ at $95 \%$ were calculated for $\mathrm{DO}, \mathrm{NH}_{4}{ }^{+}, \mathrm{NO}_{2}^{-}, \mathrm{pH}$, salinity, temperature, and water clarity parameters. Phytoplankton abundance and biodiversity were analyzed using ShannonWiener (H') index (Cardoso et al. 2012; El Gammal et al. 2017; Riris et al. 2017; Sahami et al. 2017). Phytoplankton abundance (cells $/ \mathrm{mL}$ ) was calculated based on number of counted phytoplankton cells divided by the volume of filtered water. Shannon-Wiener diversity (H') was used to calculate and denoted as:

$$
\mathrm{H}^{s}=-\sum_{\mathrm{i}=1}^{s}[\mathrm{pi} \ln (\mathrm{pi})]
$$

Where $\mathrm{Pi}$ is the proportion of the species $\mathrm{i}$ phytoplankton in total individuals.

The water quality parameter, phytoplankton abundance, and biodiversity data were then subjected to Principle Component Analysis (PCA). In PCA, these parameters were selected as independent variables with eigenvalues greater than 1.0, which were considered significant to determine the number of principal components.

\section{RESULTS AND DISCUSSION}

\section{Water quality parameters}

Figure 2 shows the average water quality parameters in brackish water shrimp ponds with nanobubble and without nanobubble treatment (control), while Figure 3 illustrates the PCA of those water quality parameters. The first principal component (Component 1 axis/horizontal axis) had high loadings of salinity (0.99), temperature (0.99) and $\mathrm{NH}_{4}{ }^{+}$(0.84). Similarly, the second principal component (Component 2 axis/vertical axis) also had high loadings of $\mathrm{NO}_{2}^{-}(0.97)$, DO (0.75) and clarity (0.51). According to the PCA, there are three groups of correlations. First, the correlation of salinity with temperature and $\mathrm{NH}_{4}{ }^{+}$, and second, the correlation of water clarity with $\mathrm{DO}$ and $\mathrm{NO}_{2}$ Lastly, the phytoplankton cell abundance was positively correlated with the $\mathrm{pH}$ followed by correlation with water clarity, DO, and $\mathrm{NO}_{2}^{-}$. Nonetheless, the phytoplankton abundance has negative correlation with salinity, temperature, and $\mathrm{NH}_{4}{ }^{+}$.

\section{Phytoplankton abundance}

A total of 11 phytoplankton species was recorded in the nanobubble treatment pond and control pond during 21-day 
observations. These species were grouped under five major divisions of phytoplankton, including Cryptophyta = Chrysophyta $=$ Cyanophyta $>$ Chlorophyta $=$ Pyrrophyta (Table 2). The phytoplankton belongs to Cryptophyta, Chrysophyta, and Cyanophyta were dominant and recorded in nearly all samples. Whereas Chlorophyta and Pyrrophyta were less dominant since they were almost absent in samples. Species that were showing a constant increase in abundance were Pleurosigma sp., Nitzchia sp., Anabaena sp., Oscillatoria sp., and Microcystis sp. Meanwhile, some species showed fluctuations in abundance, such as Gymnodium sp., Chlamydomonas sp., and Prymnesium sp. In comparison, species that showed a declining in abundance trend were Chlorella sp. and Amphora sp., while Cryptomonas sp. abundance was relatively stable.
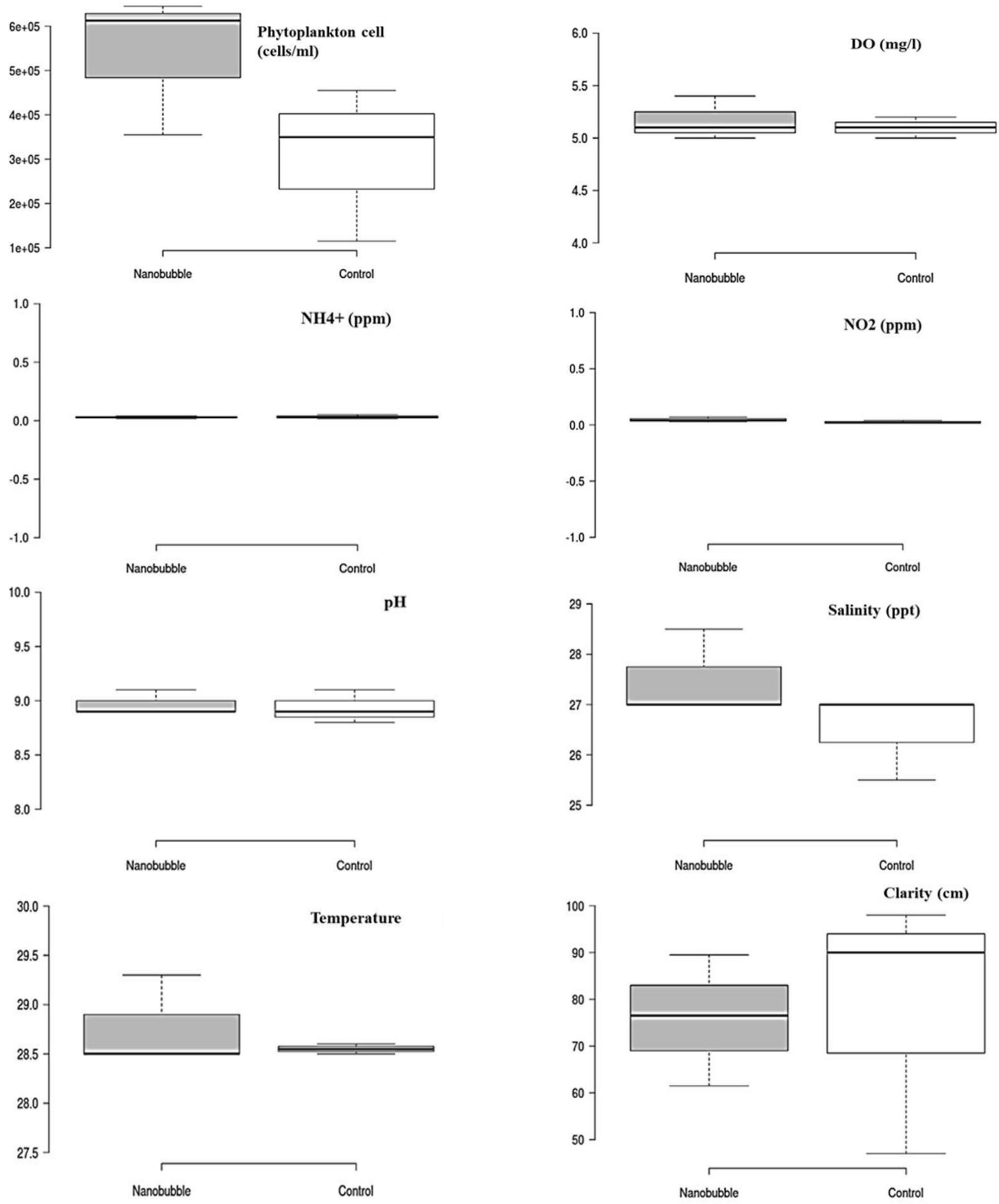

Figure 2. Average water quality parameters (phytoplankton cell, $\mathrm{DO}, \mathrm{NH}_{4}^{+}, \mathrm{NO}_{2}{ }^{-}, \mathrm{pH}$, salinity, temperature, water clarity) in brackish water shrimp ponds with nanobubble and without nanobubble treatment (control) 


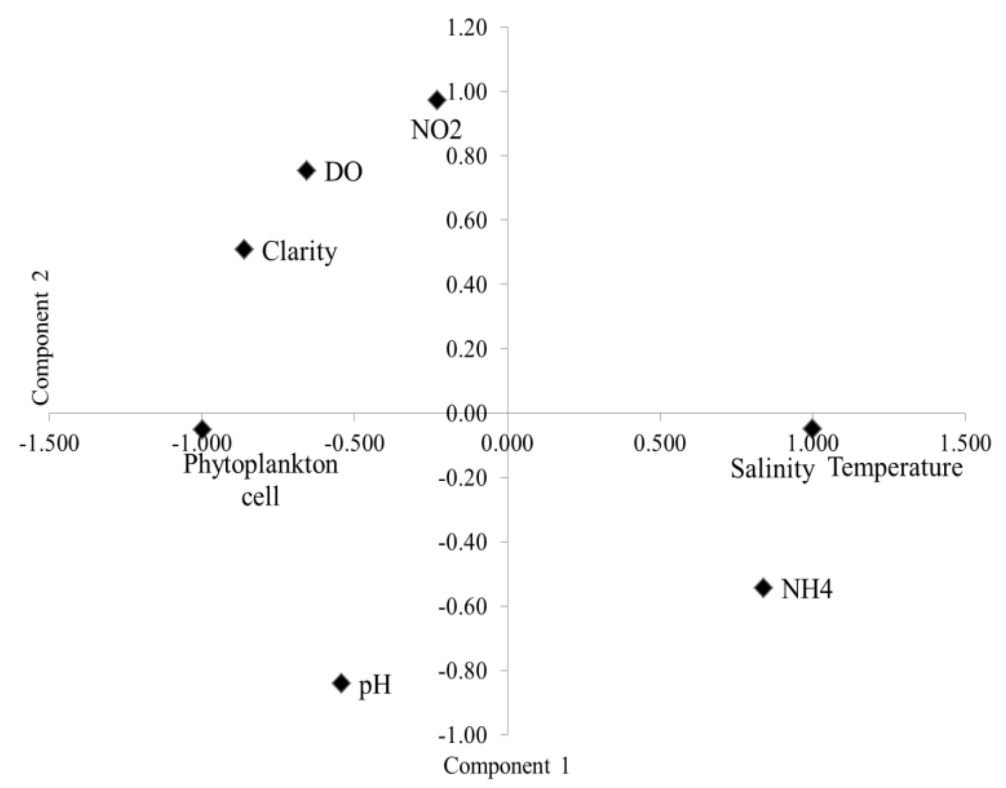

Figure 3. PCA of water quality parameters in brackish water shrimp pond with nanobubble aeration treatment

Table 2. Phytoplankton species and abundance (cells $/ \mathrm{mL}$ ) in brackish water shrimp ponds with and without nanobubble aeration treatment (control) for 7, 14, and 21 days

\begin{tabular}{|c|c|c|c|c|c|c|}
\hline \multirow{3}{*}{ Species } & \multicolumn{6}{|c|}{ Days of treatment } \\
\hline & \multicolumn{2}{|c|}{7 days } & \multicolumn{2}{|c|}{14 days } & \multicolumn{2}{|c|}{21 days } \\
\hline & Nanobubble & Control & Nanobubble & Control & Nanobubble & Control \\
\hline \multicolumn{7}{|l|}{ Chlorophyta } \\
\hline Chlorella sp. & 20000 & - & - & - & - & - \\
\hline \multicolumn{7}{|l|}{ Pyrrophyta } \\
\hline Gymnodium sp. & - & - & 10000 & 2500 & - & 10000 \\
\hline \multicolumn{7}{|l|}{ Cryptophyta } \\
\hline Chlamydomonas sp. & 10000 & - & 280000 & 10000 & 60000 & 80000 \\
\hline Cryptomonas sp. & 10000 & - & 10000 & 20000 & 10000 & 10000 \\
\hline Prymnesium sp. & - & - & 30000 & 40000 & - & - \\
\hline \multicolumn{7}{|l|}{ Chrysophyta } \\
\hline Amphora sp. & 540000 & 280000 & 10000 & 7500 & - & 5000 \\
\hline Pleurosigma sp. & - & - & 2500 & - & 5000 & 10000 \\
\hline Nitzchia sp. & - & - & - & - & 50000 & - \\
\hline Chaetoceros sp. & - & - & - & 5000 & - & - \\
\hline \multicolumn{7}{|l|}{ Cyanophyta } \\
\hline Anabaena sp. & 2500 & 20000 & 2500 & 10000 & 20000 & - \\
\hline Oscillatoria $\mathrm{sp}$ & 30000 & 50000 & 300000 & 340000 & 200000 & 1000000 \\
\hline Anabaenopsis sp. & - & - & - & 10000 & - & - \\
\hline Microcystis sp. & - & - & - & 10000 & 10000 & - \\
\hline Number of species & 6 & 3 & 8 & 10 & 7 & 6 \\
\hline Mean & 47115 & 26923 & 49615 & 35000 & 27307 & 85769 \\
\hline Standard error \pm & \pm 41156 & \pm 21465 & \pm 29700 & \pm 25590 & \pm 15407 & \pm 76422 \\
\hline
\end{tabular}

At the initial nanobubble aeration treatment phase or after seven days (Figure 4), the Chrysophyta constituted over $50 \%$ of the total phytoplankton algae with the Amphora sp. abundance dominated the pond by $88 \%$. In addition, other species abundance order was as follow Oscillatoria sp. > Chlorella sp. > Chlamydomonas sp. > Cryptomonas sp. On the $14^{\text {th }}$ day of nanobubble treatment, the Amphora sp. abundance was succeeded by the bloom of
Chlamydomonas sp. and Oscillatoria sp. At this time the abundance order was Oscillatoria sp. > Chlamydomonas sp. > Prymnesium sp. $>$ Amphora sp. = Cryptomonas sp. $=$ Gymnodium sp. > Pleurosigma sp. = Anabaena sp. After 21 days of nanobubble treatment, the phytoplankton abundance order was Oscillatoria sp. > Chlamydomonas sp. > Nitzchia sp. > Anabaena sp. > Cryptomonas sp. > Pleurosigma sp. In control pond, results showed an 
increase in number of species Gymnodium sp. and Chlamydomonas sp. on the $14^{\text {th }}$ and $21^{\text {st }}$ day, from 2500 to 10000 and from 10000 to 80000 cells/mL, respectively. The phytoplankton belong to Amphora sp. was noted to be dominant on the $7^{\text {th }}$ day, while the species that showed a declining abundance trend were Anabaena sp. and Amphora sp. from day $7^{\text {th }}$ until day $21^{\text {st }}$, and Cryptomonas sp. from day $14^{\text {th }}$ to $21^{\text {st }}$. In contrast, species that showing a constant increase in abundance was Oscillatoria sp. from 50000 on day $7^{\text {th }}, 340000$ on day $14^{\text {th }}$, and 1000000 on day $21^{\text {st }}$.

\section{Phytoplankton biodiversity}

Results show an increase in number of species and biodiversity index (H') after 21 days of nanobubble treatment. On the $7^{\text {th }}$ day of the treatment, the number of phytoplankton species was only 6 (Table 2 ), while on the $14^{\text {th }}$ day there was an increase in number of species from 6 to 8 species or increased by $33 \%$. The new species observed on the $14^{\text {th }}$ and $21^{\text {st }}$ day of nanobubble treatment were Gymnodium sp., Prymnesium sp., Nitzchia sp., and Microcystis sp. Regarding the biodiversity, number of days of nanobubble treatment can increase the $H^{\prime}$ of phytoplankton. An increase of $\mathrm{H}^{\prime}$ from the $7^{\text {th }}$ to the $21^{\text {st }}$ day of treatment with nanobubble can be observed in Figure 5. On the $7^{\text {th }}$ day, the H' was 0.322 (95\%CI: $0.074-$ $0.718)$. The $H^{\prime}$ increased continuously to $0.332(95 \% \mathrm{CI}$ : $0.051-0.613)$ on $14^{\text {th }}$ day until it reached $0.561(95 \% \mathrm{CI}$ : $0.208-0.916)$ on the $21^{\text {st }}$ day. The use of nanobubble has improved the phytoplankton biodiversity up to $74 \%$. While in control pond, the H' was 0.199 (95\% CI: $0.000-0.520)$ on the $7^{\text {th }}$ day and increased to 0.666 (95\% CI: $\left.0.335-0.997\right)$ on the $14^{\text {th }}$ day. Nonetheless, the H' reduced to $0.326(95 \% \mathrm{CI}$ : $0.000-0.683$ ) on the $21^{\text {st }}$ day.

The phytoplankton biodiversity in this study included several divisions. All phytoplankton divisions had positive correlations with the days of treatment. Those positive correlations between H' and days of nanobubble treatment were observed in Chrysophyta $\left(\mathrm{r}^{2}=0.363\right)$, Cyanophyta $\left(\mathrm{r}^{2}\right.$ $=0.219)$, and Cryptophyta $\left(r^{2}=0.217\right)$ (Figure 6). Figure 6 also illustrates that after 21 days of treatment, the biodiversity of Cyanophyta, Chrysophyta, and Cryptophyta increased by $72 \%, 60 \%$, and $31 \%$, respectively.

The PCA (Figure 7) has grouped the 11 phytoplankton species into several groups. First group consists of Amphora sp. and Chlorella sp. and second group is Prymnesium sp. and Gymnodium sp., while the third group includes five species (Anabaena sp., Chlamydomonas sp., Cryptomonas sp., Oscillatoria sp., Pleurosigma sp.). The last group only consisted of Microcystis sp. and Nitzchia sp. The first principal component (Component 1 axis/horizontal axis) had high loadings of Gymnodium sp. (0.047) and Prymnesium sp. (0.046), while the second principal component (Component 2 axis/vertical axis) had high loadings of Gymnodium sp. (0.99), Prymnesium sp. (0.99), Chlamydomonas sp. (0.98), Oscillatoria sp. (0.84), Cryptomonas sp. (0.63), Pluerosigma sp. (0.44) and Amphora sp. (0.09).
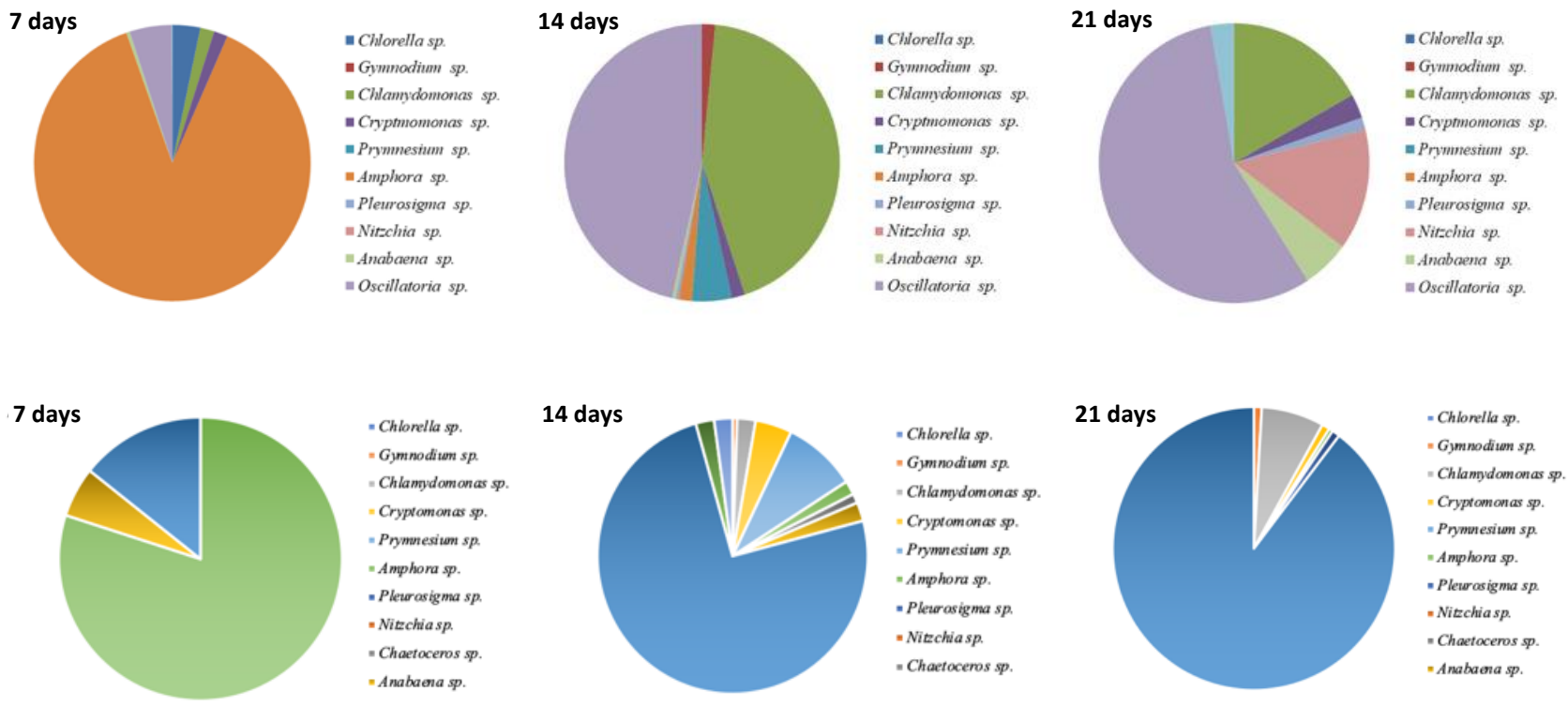

Figure 4. The composition trend of phytoplankton abundance in brackish water shrimp ponds with nanobubble (above) and without treatment (below) for 7, 14, and 21 days 

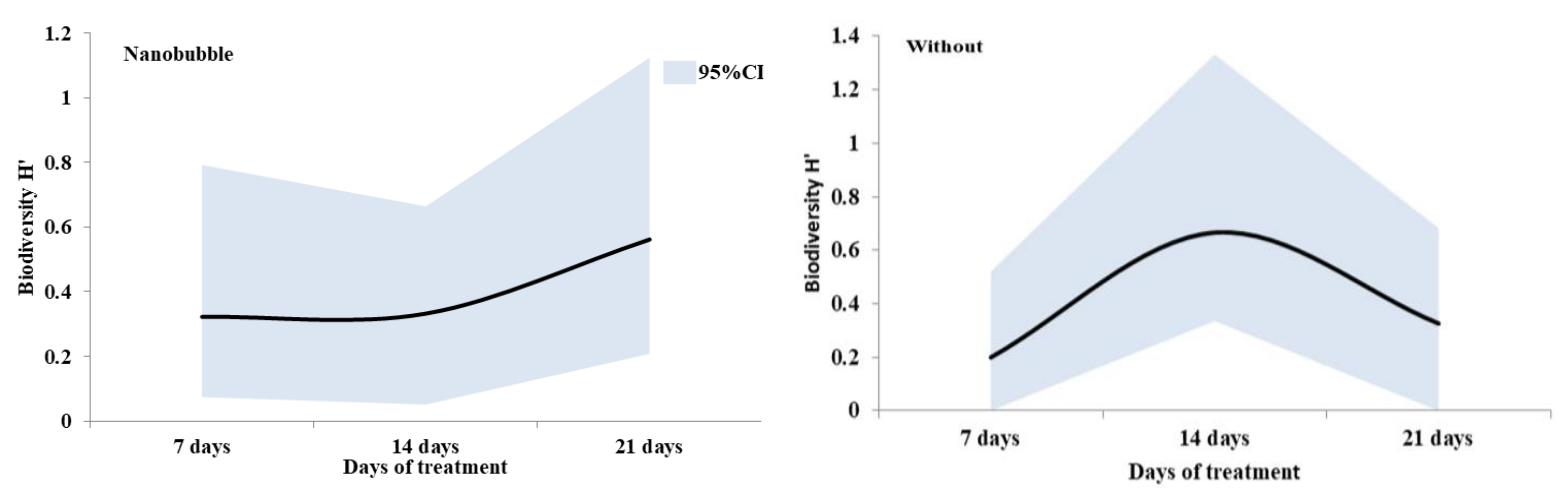

Figure 5. The mean values and $95 \% \mathrm{CI}$ (shaded area) of phytoplankton biodiversity Shannon-Wiener index (H') in brackish water shrimp ponds with nanobubble (left) and without nanobubble treatment (right) for 7, 14, and 21 days
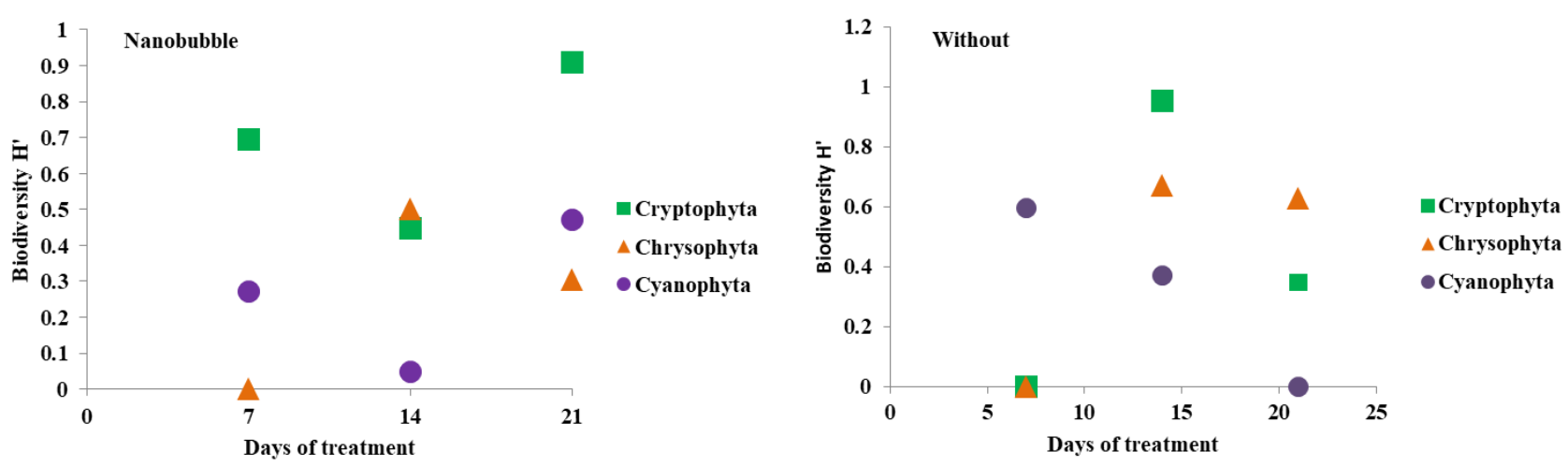

Figure 6. The correlation of phytoplankton division biodiversity Shannon-Wiener index (H') with days in brackish water shrimp ponds with nanobubble (left) and without nanobubble treatment (right) for 7, 14, and 21 days

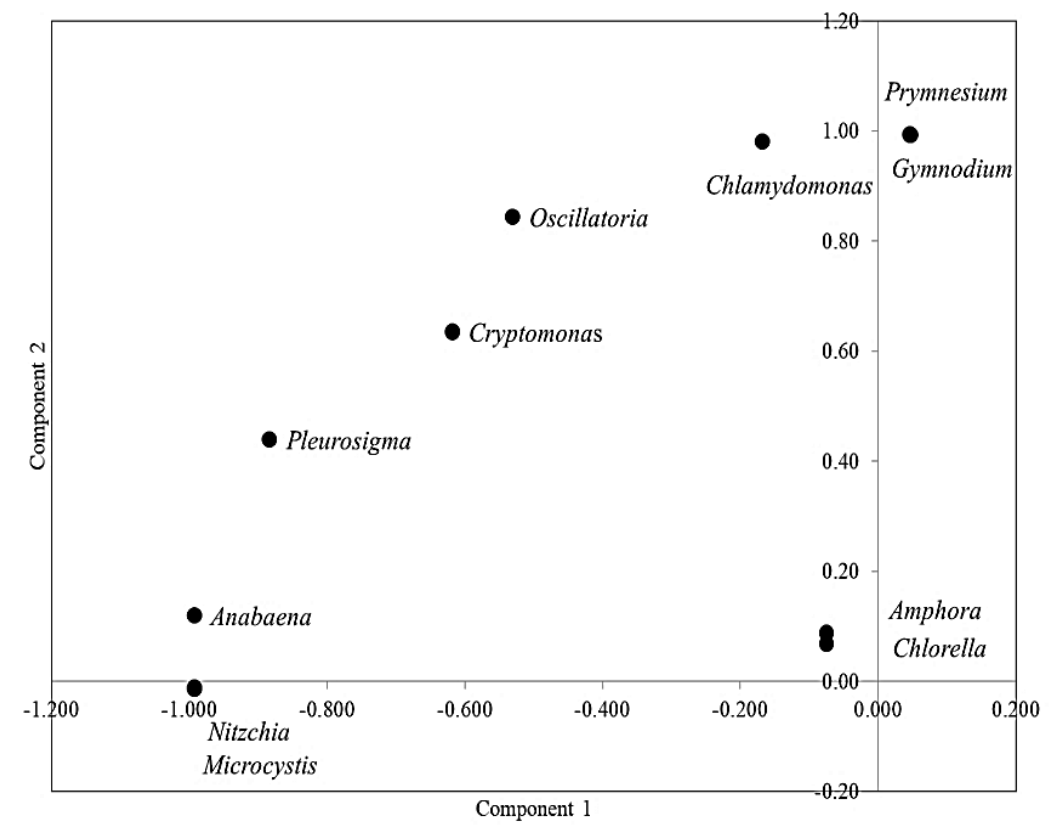

Figure 7. PCA of phytoplankton species in brackish water shrimp ponds with nanobubble aeration treatment for 7, 14, and 21 days 


\section{Discussion}

Numerous studies have attempted to improve water quality and phytoplankton abundance and biodiversity simultaneously. Cremen et al. (2007) have used green water technology to improve phytoplankton community composition, density, and succession in tropical commercial ponds in the Philippines. Onada et al. (2015) conducted a comparative study of earthen and concrete shrimp ponds, while Sahabuddin et al. (2019) integrated rice cultivation with shrimp pond to increase Oscillatoria sp. population. In this study, the use of nanobubble aeration treatment has been proposed with the aim to improve water quality, in particular, DO level and increase phytoplankton biodiversity, as well as abundance. Water quality parameters were the indicators for nanobubble performances.

The water quality parameters resulted from the use of nanobubble treatment were comparable to other studies (Kimpara et al. 2013; Alfiansah et al. 2020). According to PCA (Figure 3), the phytoplankton cell abundance followed by water clarity, $\mathrm{DO}$, and $\mathrm{NO}_{2}^{-}$trends since phytoplankton requires clear water to perform photosynthesis (Burford 2008), DO for respiration, and N as sources of nutrient. The correlation between DO and phytoplankton abundance was related to the constants supply of DO considering that the ponds were receiving constant $\mathrm{O}_{2}$ supply from the nanobubble machine. As a result, the mean DO for 21-day observation was also higher than the DO level in conventional ponds, as recorded by other studies. In traditional brackish ponds with conventional aeration systems, the DO ranged from 3.76 to $4.7 \mathrm{mgL}^{-1}$ (Sudinno et al. 2015; Utojo 2015). The nanobubble in this study was able to maintain the DO level as high as $5.17 \mathrm{mgL}^{-1}$ (95\%CI: 4.93-5.41). Nonetheless, the inverse correlation of phytoplankton abundance with salinity was also reported by Umamaheswararao et al. (2015). Due to dilution and evaporation, salinity is known as a limiting factor that influences the distribution of phytoplankton in the coastal ecosystem. The phytoplankton abundance with DO also had negative correlation with temperature. Joseph (2017) reported that phytoplankton avoids high-temperature water since the solubility of oxygen decreases as the water temperature increases.

Abundance of phytoplankton divisions recorded in this study is comparable to other studies. Cyanophyta was dominant and had higher abundance in comparison to other taxonomic groups. Cremen et al. (2007) reported that the Cyanophyta had the highest mean density followed by Chlorophyta and the Bacillariophyta. Meanwhile, Chlorophyta had lower abundance than Cyanophyta and Bacillariophyta was absent. At the species level, Cremen et al. (2007) found that the phytoplankton species order trend was Nannochloropsis sp. > Oscillatoria sp. > Euglena sp. > Anabaena sp. In addition, this study also found that Anabaena sp. consistently outnumbered by Oscillatoria sp.

The application of nanobubble in brackish water shrimp pond has increased the Amphora sp. abundance followed by Oscillatoria sp. and Chlorella sp. as can be seen on the $7^{\text {th }}$ day. Amphora sp. was under the Chrysophyta group and this phytoplankton group is known as the pioneer species and has high tolerance to the environmental condition
(Kristiansen and Skaloud 2016). According to Manurung et al. (2015), high abundance of Chrysophyta plankton outnumbered other groups. The presence of Chrysophyta species was due to its ability to inhabit high-temperature water with low nitrogen content. The preferred temperature range was $31-32^{\circ} \mathrm{C}$ and the ammonia content range was 0.1-0.5 mg. $\mathrm{L}^{-1}$.

On the $14^{\text {th }}$ and $21^{\text {st }}$ day, Oscillatoria sp. and Chlamydomonas sp. abundance surged and replaced Amphora sp. and Chlorella sp. The PCA (Figure 7) also shows that Amphora sp. and Chlorella sp. are grouped together and have negative correlation with Oscillatoria sp. and Chlamydomonas sp. Furthermore, Chlorella sp. was under Chlorophyta and the species under this division is known as dominant algae, especially during the initial culture phase. After several days, Chlorophyta abundance declined and was replaced by species from other divisions. Cremen et al. (2007) explained that Oscillatoria sp. and Chlamydomonas sp. can replace the Chlorella sp. due to a decline in salinity and high $\mathrm{P}$ content. The phytoplankton species PCA grouping, as can be observed in Figure 7, agrees with the findings reported by Zębek and Szymańska (2017). In their observation, Chlamydomonas sp. was commonly accompanied by Cryptomonas sp.

Number of the phytoplankton species recorded in this study, which was 11 species, was comparable to other similar studies. Utojo (2015), in which the research was also conducted on Probolinggo coast, has confirmed 13 species. Several species in this study were also found in research by Utojo (2015), including Nitzchia sp., Pluerosigma sp., and Oscillatoria sp. Also, species found in Rembang, Central Java, and Subang, West Java were 14 and 10 species, respectively. (Sudinno et al. 2015; Umami et al. 2018). Hence, this result provides evidence that the nanobubble induced ponds are able to have similar phytoplankton species to ponds without nanobubble treatment. Table 3 compares results obtained in this study with other studies in terms of aeration treatment, DO, and H'. The DO levels are generally higher in the ponds with aeration treatments compared to the ponds without aeration treatments. Whereas, the DO resulted from nanobubble treatment has the highest values in comparison to DO yielded from other aeration treatments, and the DO levels were also affecting the H'. In this study, recorded phytoplankton H' was observed higher than the results from Ikpi et al. (2013) and Utojo and Mustafa (2016). To conclude, the nanobubble aeration treatment can be used as a solution to improve water quality and increase phytoplankton diversity and abundance in brackish water shrimp ponds.

Table 3. Comparisons of phytoplankton biodiversity index (H') in brackish water shrimp pond with other aeration treatments

\begin{tabular}{llrc}
\hline \multicolumn{1}{c}{ Author } & $\begin{array}{c}\text { Aeration } \\
\text { treatment }\end{array}$ & DO $\left(\mathbf{m g L}^{-\mathbf{1}}\right)$ & H' \\
\hline Ikpi et al. (2013) & W/o aeration & $4.9-4.8$ & $0.115-0.540$ \\
Sudinno et al. (2015) & W/o aeration & $3.0-4.7$ & $0.350-1.273$ \\
Umami et al. (2018) & Fan & $4.0-4.3$ & $1.420-2.160$ \\
Utojo and Mustafa (2016) Fan & $3.7-4.5$ & $0.100-1.260$ \\
This study (2020) & Nanobubble & $5.0-5.4$ & $0.332-0.561$ \\
\hline
\end{tabular}




\section{ACKNOWLEDGEMENTS}

The authors are grateful to the Universitas Indonesia for the funds provided through the Directorate of Research and Community Service (DRPM UI) under PUTI 2020-2021 funding scheme. The authors would like to express our gratitude to Guruh Suryawan for the onsite research opportunities, as well as to Arini and Ichwan Rosidi for their guidance. The nanobubble machinery was provided by Nanobubble Karya Indonesia Ltd., South Tangerang, Indonesia, and patented by Pusat Penelitian Fisika LIPI No. P00201903600.

\section{REFERENCES}

Alfiansah YR, Peters S, Harder J. 2020. Structure and co-occurrence patterns of bacterial communities associated with white faeces disease outbreaks in Pacific white-leg shrimp Penaeus vannamei aquaculture. Sci Rep 10: 11980. DOI: 10.1038/s41598-020-68891-6.

Alonso-Rodríguez R, Paéz-Osuna F. 2003. Nutrients, phytoplankton and harmful algal blooms in shrimp ponds: A review with special reference to the situation in the Gulf of California. Aquac 219 (1-14): 317-336. DOI: 10.1016/S0044-8486(02)00509-4.

Araújo SC, Garcia VMT. 2005. Growth and biochemical composition of the diatom Chaetoceros cf. wighamii Brightwell under different temperature, salinity and carbon dioxide levels. I.Protein, carbohydrates and lipids. Aquac 246 (1-4): 405-412. DOI: 10.1016/j.aquaculture.2005.02.051.

Burford M. 2008. Phytoplankton dynamics in shrimp ponds. Aquac Res 28 (5): 351-360. DOI: 10.1046/j.1365-2109.1997.00865.x.

Cardoso SJ, Roland F, Loverde-Oliveira SM, Huszar VL. 2012. Phytoplankton abundance, biomass and diversity within and between Pantanal wetland habitats. Limnologica 42 (3): 235-241. DOI: 10.1016/j.limno.2012.01.002.

Case M, Leca EE, Leitao SN, Anna EES, Schwamborn R, Junior ATM. 2008. Plankton community as an indicator of water quality in tropical shrimp culture ponds. Mar Pollut Bull 56 (7): 1343-1352. DOI: 10.1016/j.marpolbul.2008.02.008.

Cremen MC, Martinez-Goss M. Corre V, Azanza R. 2007. Phytoplankton bloom in commercial shrimp ponds using green-water technology. J Appl Phycol 19 (6): 615-624. DOI: 10.1007/s10811-007-9210-7.

El Gammal MAM, Nageeb M, Al-Sabeb S. 2017. Phytoplankton abundance in relation to the quality of the coastal water - Arabian Gulf, Saudi Arabia. Egypt J Aquat Res 43 (4): 275-282. DOI: 10.1016/j.ejar.2017.10.004

Ikpi GU, Offem BO, Okey IB. 2013. Plankton distribution and diversity in tropical earthen fish ponds. Environ Nat Resour Res 3 (3): 45-51. DOI: $10.5539 /$ enrr.v3n3p45.

Joseph J. 2017. Diversity and distribution of phytoplankton in an artificial pond. Intl J Adv Res Biol Sci 4 (5): 114-122. DOI: 10.22192/ijarbs.2017.04.05.013.

Kimpara JM, Moraes-Valenti PMC, Queiroz J, New MB. 2013. Effects of intensification of the amazon river prawn, Macrobrachium amazonicum, grow-out on effluent quality. J World Aquac Soc 44 (2): 210. DOI: 10.1111 jwas. 12021 .

Kristiansen J, Skaloud P. 2016. Chrysophyta. Handbook of the Protists. Springer International Publishing, US. DOI: 10.1007/978-3-31928149-0_43.

Mahasri G, Saskia A, Apandi P, Dewi NN, Rozi, Usuman NM. 2018. Development of an aquaculture system using nanobubble technology for the optimation of dissolved oxygen in culture media for Nile tilapia (Oreochromis niloticus). IOP Conf Ser Earth Environ Sci 137: 012046. DOI: 10.1088/1755-1315/137/1/012046.
Mansyah YP, Mardhia D, Ahdiansyah Y. 2020. Identifikasi jenis fioplankton di tambak udang Vannamei (Litopenaeus vannamei) LSO AV3 Kecamatan Utan Kabupaten Sumbawa. Indon J Appl Sci Technol 1 (1): 20-28.

Manurung N, Setyawati TR, Mukarlina. 2015. Produktivitas primer danau lait Kecamatan Tayan Hilir ditinjau dari kelimpahan dan kandungan klorofil-a fitoplankton. Protobiont 4 (2): 30-39.

Morsy F. 2011. A simple approach to water and plankton sampling for water microbiological and physicochemical characterizations at various depths in aquatic ecosystems. Annales de Limnologie - Intl J Limnol 47 (1): 65-71. DOI: 10.1051/limn/2010032.

Newell GE, Newell RC. 1977. Marine Plankton; A Practical Guide. Hutchinson \& Co Ltd. London.

Ohmori M, Haruta K, Kamimura S, Koike H, Uchida T, Takeyama H. 2015. A simple method for nanobubble generation and stability of the bubbles. J Environ Biotechnol 15 (1): 41-44.

Onada OA, Akinwole AO, Ajani EK. 2015. Study of interrelationship among water quality parameters in earthen pond and concrete tank. PeerJPrePrints 3: e845v1. DOI: 10.7287/peerj.preprints.845v1.

Riris A, Bengen D, Prartono T, Zulkifli H. 2017. Abundance of phytoplankton in the coastal waters of South Sumatera. Indon J Mar Sci 22 (1): 31-39. DOI: 10.14710/ik.ijms.22.1.31-39.

Sahabuddin, Sahrijanna A, Suwoyo HS. 2019. Increased Oscillatoria sp. population on integrated cultivation ponds of rice and tiger shrimp (Penaeus monodon) in Idle Land. Intl J Environ Agric Biotechnol 4 (6): 1814-1819.

Sahami FM, Baruadi ASR, Hamzah SN. 2017. Phytoplankton abundance as a preliminary study on pearl oyster potential culture development in the North Gorontalo water, Indonesia. AACL Bioflux 10 (6): 15061513 .

Sudinno D, Jubaedah I, Anas P. 2015. Water quality and pond in coastal communities plankton Subang Regency West Java. Jurnal Penyuluhan Perikanan dan Kelautan 9 (1): 13-28.

Takarina ND, Wardhana W, Soedjiarti T. 2017. Impact of oxygen depletion on planktonic community with emphasis temperature dynamics at aquaculture scale in Blanakan, West Java. AIP Conf Proc 1848. DOI: $10.1063 / 1.4983932$.

Temesgen T, Bui TT, Han M, Kim T, Park H. 2017. Micro and nanobubble technologies as a new horizon for water-treatment techniques: A review. Adv Colloid Interface Sci 246: 40-51. DOI: 10.1016/j.cis.2017.06.011.

Tomas CR. 1997. Identifying Marine Phytoplankton. Academic Press, United States.

Umamaheswararao R, Janakiram P, Sreedhar U, Rushinadharao K, Lavanya S. 2015. Phyto plankton bio-diversity in tiger shrimp (Penaeus monodon) cultured pond under natural conditions at Bheemili, Visakhapatnam. Intl J Multidiscip Educat Res 4 (112): 198202.

Umami R, Hariyati. Utami S. 2018. Keanekaragaman fitoplankton pada tambak udang vaname (Litopenaeus vannamei) di Tireman Kabupaten Rembang Jawa Tengah. Jurnal Akademika Biologi 7 (3): 27-32.

Utojo U. 2015. Keragaman plankton dan kondisi perairan tambak intensif dan tradisional di Probolinggo Jawa Timur. Biosfera 32 (2): 83-97. DOI: 10.20884/1.mib.2015.32.2.299. [Indonesian]

Utojo U, Mustafa A. 2016. Plankton community structure of traditional and intensive brackishwater ponds in Probolinggo regency, East Java Province. Jurnal Ilmu dan Teknologi Kelautan Tropis 8 (1): 269-288. DOI: 10.29244/jitkt.v8i1.13467.

Wang Y, Liu Y, Sun Y, Jin Z, Zhao Z. 2018. Primary application of nanobubble technology in shrimps. Fish Modernization 45 (2): 21.

Yamaji. 1984. Illustration of the Marine Plankton of Japan. Hoikusha, Japan.

Zębek E, Szymańska U. 2017. Abundance, biomass and community structure of pond phytoplankton related to the catchment characteristics. Knowl Manag Aquat Ecosyst 418: 45. DOI: $10.1051 / \mathrm{kmae} / 2017036$. 